\title{
Research on the Teaching Management of Colleges and Universities Based on Innovative Talents Training
}

\author{
Lixin Fan \\ School of Humanities, Jilin Agricultural University, Changchun 130118, China
}

(E-mail:897146503@qq.com)

Keywords: Innovative talents; Colleges and universities; teaching management

\begin{abstract}
Innovative talents training plays an important role in economic development and social progress. In order to cope with the challenges of the times, higher education must pay attention to the cultivation of students' innovative ability. And as a direct impact on the cultivation of innovative talents, teaching management is particularly important. The teaching management in Colleges and universities restricts the cultivation of creative talents. As a result, we must work hard to promote the innovation of teaching management, and clear the way and create conditions for the cultivation of innovative talents. This paper is based on innovative talents training of College teaching management research, according to the analysis of the current situation to propose the corresponding countermeasures.
\end{abstract}

\section{Introduction}

Innovation is an important driving force for the progress of human civilization, which has greatly promoted the progress of human civilization. Comrade Jiang Zemin once pointed out: "Innovation is the soul of the national progress, and it is the inexhaustible motive force for the prosperity of the country." "To meet the rapid development of science and technology and the challenge of rapid rise of knowledge, the most important thing is to adhere to innovation." "A nation that cannot be innovative is a nation without hope." Under the background of the era of knowledge economy, the competition between nations is embodied in the competition of science and technology; the fifth Plenary Session of the 16th CPC Central Committee of the Party also pointed out to take independent innovation as the strategic basis for the future development of technology [1]. However, the main channel of cultivation of innovative talents is education. Therefore, innovative education, which is the core of innovative talents training, puts forward new challenges and higher requirements for the current teaching management in Colleges and universities in China. The social background of independent innovation calls for more innovative talents, and the cultivation of innovative talents depends on the process of innovative teaching management. In this situation, it is necessary to reform the traditional teaching management that suppresses the full play of enthusiasm and creativity of students and implement teaching management that is effective and conductive to cultivate innovative talents, so as to cultivate more innovative and comprehensive talents matched the social requirements for our country.

\section{Theoretical Basis of Teaching Management in Colleges and Universities Based on Innovative Talents Training}

\subsection{Education Management System}

The university is a social function system, composed of three sub-systems of the main system (the system is directly responsible for specialized personnel training task), support system (the main system to ensure the system of teaching work to work from the manpower, materials, money and so on), and control system (the system manages, commands, and controls the main system and support system). The control system is the teaching management system. Teaching management itself is a complex system project, composed of its own main system, control system, and support system. Teaching management system refers to, under the leadership of the Party Committee and the head of the University, form a flexible operation, authoritative, and efficient management system. 
Teaching management system takes to improve the quality of teaching as the core, to cultivate high-quality talents as the objective, reasonably organize various links of the teaching process and the various departments of the activities, each system mutually connects, coordinates and promotes, and forms an organic whole with clear task, duty, and right.

The teaching activity is the multilateral activity that teachers, students and teaching management staffs all participate in. Therefore, in the operation process of teaching management system, it is necessary to give full play to the coordination function of the system, let the three aspects of personnel effectively coordinate, timely understand the teaching effect of teachers, give feedback of the students' learning quality information, and put forward the new management objectives, so as to make the teaching work and management running and developing at a new starting point and high level. Teaching management system structure can be expressed in Figure 2-1 [2].

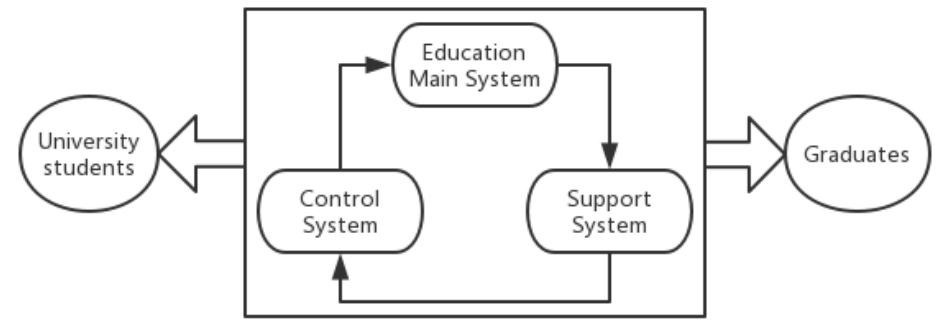

Figure 2-1 Teaching management system structure

\subsection{Total Quality Management}

The total quality management theory is originally applied to the enterprises, but with the arrival of the era of knowledge economy, to improve the quality of education as the theme of world education has increasingly become the focus of attention. Introduce the theory of total quality management in modern enterprise management into the teaching management in Colleges and universities, and establish a teaching management theory taking comprehensive quality management as the target. Take the quality as the center and the participation of staffs and students as the foundation, stress on the application of quality management principles of "Quality first, comprehensive control, full participation, whole process control, flexible use, prevention, and continuous improvement" in teaching management, and emphasize comprehensive management of the development of students' morality, wisdom, and body, and multiple factors and links of the process of teaching. This kind of management is whole-staff management that teachers and students, teaching assistants, the teaching management staffs, and all the staffs serve the teaching to participate in and accept management. It is also the quality management of concept of teaching management, teaching plan process, teaching operation process, and teaching construction process and so on.

The basic method of comprehensive quality management theory, namely the PDCA cycle method, is shown in Figure 2-2 [3], with four stages and eight steps to show repeated cycle procedures; four stages are the planning stage (Plan): to discover and analyze problems, find out the reasons, take measures, and develop plans; the implementation stage (Implement): according to the strategy to carefully implement; the inspection stage (Inspect): based on the plan, inspect, investigate and analyze practical implementation and implementation effect of countermeasures; the processing stage (Handle): To summarize the successful experience in the implementation of countermeasures, and handle the error, implement countermeasures unsuccessful or remaining problems to the next PDCA cycle.

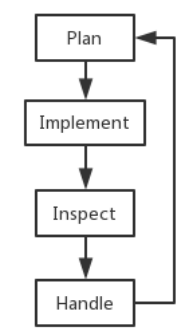

Figure 2-2 The PDCA cycle method 


\section{Analysis of Current Situation of College Teaching Management Based on the Cultivation of Innovative Talents}

\subsection{Backward Teaching Management Team Construction and Management Concept Restricting the Development of Innovative Talents Training}

The cultivation of innovative talents is the basic functions of Colleges and universities and the cultivation of innovative talents throughout the whole process of teaching. In consequence, as the subject of management, the direct organizer of the teaching activities, and the planners of school training objectives, teaching manager plays an important role in the process of cultivation of innovative talents. The overall quality of the teaching management team has a direct impact on the educational level and educational quality of the university. In the face of the higher requirements for the quality of talents training in the new era, the university must have a high quality teaching management team with advanced management ideas, reasonable management knowledge, and strong business ability.

But in the reality, teaching management team is relatively weak, most of the teaching management staff do not meet this requirement, generally lacking theories and methods of teaching management, and even a lot of people think that the teaching management is the simple work, just copy writing. The Ministry of Education in 2001 once did a sampling survey of staffs in Dean's Office in 96 universities nationwide, and the result shows that in the staffs in Dean's Office in 96 universities, those who have a doctoral degree accounts for only $7 \%$, with a master's degree accounts for only 33\%, and with a bachelor's degree accounts for only 52\%, as shown in Figure 3-1 [4].

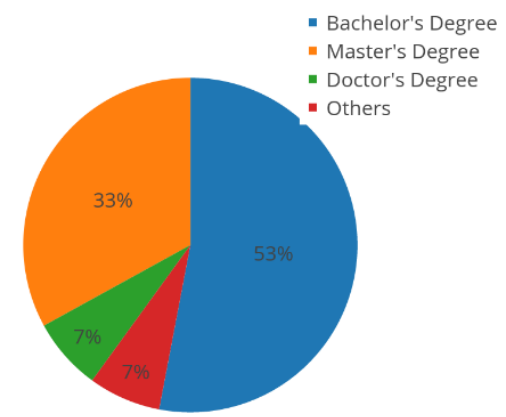

Figure 3-1 Academic staff qualifications structure chart

\subsection{Unified Teaching Plan, Narrow Specialty and Curriculum Setting and Rigid Profession Choice Seriously Restricting the Training of Innovative Talents}

On curriculum setting, for a long time, China's higher education curriculum system due to the influence of the former Soviet Union, the professional plan is too small and the curriculum is too narrow, which is not conducive to interdisciplinary synthesis, improvement of students' knowledge structure, and the improvement of migration ability. With such a curriculum system, it is impossible to develop innovative talents; in addition, for some of the courses, students learn them from primary school to College, from undergraduate to master, and repeated contents are always compulsory, so it cannot arouse the students' interest and cultivate learning ability; also, curriculum structure proportion is imbalanced.

In terms of the professional choice, the students before entering in the university do not have enough understanding of their own personality, hobbies, and other personal expertise, let alone their chosen profession, and most are chosen by parents or teachers according to their grades and currently popular professionals.

From the perspective of course selection, under the credit system, the compulsory courses prescribed are too much, therefore, the space for students to freely choose is relatively small, and the elective courses for chosen is relatively few, and in the study period arrangement, students cannot advance or delay graduation, or drop out halfway according to the personal actual situation.

\subsection{Single Teaching Management Method Not Adapt to the Training of Innovative Talents}

Present teaching management method of many Colleges and universities is still not adapted to the need of teaching operation and personnel training. The objective and organizational form of 
innovative talent training are of variety. In order to meet the needs of different cultivation objectives and the cultivation object, the higher education will develop to the direction of multi-level, multi-form, and multi-category, and entrance way, teaching form, and management form will also be diversified, while the current teaching management methods have been unable to adapt to the mode of innovative talents training [5].

Management hardware is insufficient, and many managers are not so familiar with modern teaching management technology. Because the teaching management is backward, teaching manager needs to spend a lot of manpower, material resources, and time to complete the collection of information, records, statistics, processing, collection, maintenance and delivery. While these information processing has a lot of repetitive work, large amount of information, complex data, and heavy task, so the efficiency is low and the timeliness is poor. More importantly, teaching managers spend a lot of time in these repetitive work so that they cannot calm down to be engaged in teaching management in the true meaning, or study some profound topics related to teaching management, or improve teaching management level and academic ability, or promote the cultivation of talents.

\section{Innovation of Teaching Management in Colleges and Universities Based on Innovative Talents Training}

\subsection{Innovation of Teaching Management Mode}

Form the management model taking students creative development as orientation, and actively explore the establishment of "School - College - Department (Department)" three-level system and two-level management mode, which is, in fact, to clarify the rights and responsibilities between higher school administration office and the second-level college, to moderately grade teaching management and expand the management authority of the second-level college and the management of school administration office on the second-level college, so as to activate the mechanism of running a school and improve the management efficiency of the school [6]. The second-level college is the entity of teaching management, which is mainly responsible for the teaching operation management and teaching basic construction and implementing the combination of process management and objective management in the process of teaching management. The second-level college, as the subordinate of a College, is teaching unit directly facing the first-line of teaching, not only familiar with the basic situation of the school, but also understanding the characteristics and advantages of its own. Therefore, in the premise of the overall planning and objectives established, various college need to deal with their affairs and get a better effect than dealt with by school or functional departments. At the same time, introduce the leadership accountability system, establish the teaching management mode that teachers, students, teaching managers three parties to participate in. Strengthen leadership, clarify responsibilities, encourage the teachers and students to participate in the teaching management, and mobilize the enthusiasm of the students and teachers, so as to promote the cultivation of students' creative spirit and respect students' personality development.

\subsection{Innovation of Teaching Plan}

Form the teaching process that is conducive to the promotion of personalized learning and research learning. In the professional training target, establish the concept of lifelong education and quality education, promote the common development of students' professional education and quality education, let the teaching materials highlight the basis of teaching content of College education, and cultivate students' learning ability [7]. Play the role of the network to broaden the students' knowledge, pay attention to the coordinated development of knowledge, ability, and quality, make use of the advantages of network teaching, adhere to student-centered concept, teach students in accordance with their aptitude, and cultivate students' specialty.

In the training mode, it is necessary to change a single training mode, and according to market economic demand changes to design a variety of talent training modes with intelligent structure. Give full play to the advantages of information technology, implement online education and higher distance education, provide students with sufficient space to choose, let the students free to choose the learning mode, learning, learning method, learning process, learning time, learning content, 
learning place, and learning content. Design personalized learning process and let students freely develop [8].

\subsection{Innovation of Teaching Management}

Develop modern teaching information management system which is conducive to the cultivation of innovative talents. Innovate teaching management, make use of advanced computer technology and modern network technology to develop teaching management information system and reform the teaching plan management, student result and status management, teaching material management, classroom management, teaching staffs management, teaching quality evaluation management, teaching resources management, course selection management and so on management links [9]. Construct and perfect the comprehensive teaching and educational management information service system based on campus network, so teachers and students can better grasp the information and use information reasonably, to provide a platform for the cultivation of personality and better service for the training of innovative talents.

\section{Conclusion}

Teaching management is a management work that directly services the personnel training, which has strong comprehensive and academic feature, and the cultivation of innovative talents has put forward higher requirements on teaching management in Colleges and universities. The traditional teaching management needs to adapt to it, not only to make the change of methods and means, more importantly is to improve awareness from the idea and concept [10]. This paper puts forward some innovative countermeasures by analyzing the present situation of College teaching management based on the innovation of talents training.

\section{References}

[1] Yanru B, Xu W, Xiaoning W. Reform of innovative talents' training mode under background of excellent plan[J]. Experimental Technology and Management, 2012, 3: 070.

[2] Jie W, Lu T, Yong L, et al. Exploration on cultivation of innovative talents in colleges and universities[J]. Experimental Technology and Management, 2013, 5: 048.

[3] Caiyun S. Research on training mode of high-Level innovative talents in computer science in colleges[J]. Procedia Engineering, 2012, 29: 2749-2753.

[4] WANG W, MENG X, AN Y. Exploration of the Experimental Teaching Reform under the Cultivation Model of Innovative Talents[J]. Experiment Science and Technology, 2013, 2: 053.

[5] Yunpeng G, Zhaosheng T, Fuhai L, et al. Training mode of innovative talents based on combination of open laboratory and platform for discipline competition[J]. Experimental Technology and Management, 2012, 4: 112.

[6] Fan J, Yijun W, Zhongmin X, et al. Application TRIZ to innovative ability training in the mechanical engineering major[C]//Computer Science \& Education (ICCSE), 2012 7th International Conference on. IEEE, 2012: 1464-1469.

[7] Wen-lei L I. Constructing Innovative Experimental System to Cultivate Innovative Talents[J]. Research and Exploration in Laboratory, 2016, 2: 065.

[8] Yifei L, Jinghua Z, Haiyang Y. Practice and exploration on implementing college students' innovative experiment plan and constructing innovative personnel training system based on ability cultivation[J]. Experimental Technology and Management, 2012, 7: 006.

[9] Hudson M. Increasing Corporate University Training Options within Aerospace[C]//Conference Proceedings. The Future of Education. Libreria universitaria. it Edizioni, 2016: 405.

[10] ZHAO K, FU W. Cultivating High-qualify Professional Talents Based on the Social Requirements [J][J]. The Guide of Science \& Education, 2013, 4: 009. 